\title{
ISTIHSAN: DALIL SYARÂ YANG DIPERSELISIHKAN
}

\author{
Noorwahidah \\ Dosen Fakultas Syariah dan Ekonomi Islam \\ Institut Agama Islam Negeri (IAIN) Antasari Banjarmasin
}

\begin{abstract}
Autenticity of istibsan as syarâ argument disputed by scholars. Group of Hanafiyah, Malikiyah, and most Hanabilah scholars use istibsan as an argument, but Syafiiyah, Zhabiriyah, Mu'tazili, and Sbi'a scholars reject istibsan. The dispute happened because the difference of interpreting of istibsan. The scholars who use as argument interpret istihsan as turned away from will of qiyas to more powerful qiyas or specialized qiyas because there is stronger evidence thereof, meanwhile, scholars who refuse define istihsan as all things considered good by the mujtabid by his wits. Substantively all scholars, both who use and who reject istibsan using it in some law conclusion, although scholars who reject not call it as an istibsan. They categorize it as a qiyas.
\end{abstract}

Abstrak: Kehujjahan istibsan sebagai dalil syarâ diperselisihkan oleh para ulama. Kelompok Hanafiyah, Malikiyah, dan sebagian Hanabilah menggunakannya, tetapi ulama-ulama Syafiiiyah, Zhahiriyah, Muktazilah, dan Syiah menolak. Perselisihan tersebut terjadi karena mereka berbeda dalam memberikan pengertian terhadap istibsan. Para ulama yang menggunakannya mengartikan istihsan adalah berpaling dari kehendak qiyas kepada qiyas yang lebih kuat atau pengkhususan qiyas karena ada dalil yang lebih kuat daripadanya, semenntara ulama-ulama yang menolak mendefinisikannya sebagai semua hal yang dianggap baik oleh mujtahid menurut akalnya. Secara substantif semua ulama, baik yang mendukung maupun menolak sama-sama menggunakan istihsan dalam beberapa istimbath hukum, namun ulama yang menolak tidak menyebutnya dengan istilah istibsan. Mereka mengkategorikannya sebagai qiyas.

Kata kunci: Istihsan, dalil syarâ, qiyas, maslahat, istimbath

\section{Pendahuluan}

Para ulama ahli ushul sepakat bahwa Alquran, sunah, ijmak, dan qiyas merupakan dalil syarâ (sumber hukum) di dalam Islam yang dapat dipergunakan dan dipertanggungjawabkan, namun mereka berbeda pendapat tentang beberapa dalil syarâ yang lain seperti istibsan, mashlahab mursalah, ûrf, istishab, syariat umat sebelum Islam (syarû man qablana), dan mazhab sahabat.

Perselisihan pendapat para ulama mengenai penggunaan istibsan sebagai dalil syarâ cukup keras. Ulama-ulama Hanafiyah, Malikiyah, dan sebagian Hanabilah berpendapat, istibsan dapat dijadikan sebagai dalil syarâ, sementara ulama-ulama Syafiiiyah, Zhahiriyah, Muktazilah, dan Syiah berpendapat, istibsan tidak bisa dijadikan dalil syarâ.

Imam Syafii, tokoh utama mazhab Syafii, paling keras menentang penggunaan istibsan sebagai dalil syarâ. Dengan tegas ia menyatakan, "Barangsiapa menggunakan istihsan sesungguhnya ia telah membuat syariat." ' Ungkapan ini bermakna, orang yang menggunakan istibsan berarti membuat syariat baru dan menempatkan dirinya sebagai pembentuk syariat; padahal yang berwenang membentuk syariat hanyalah Allah swt. ${ }^{2}$ Ia juga menyatakan, istihsan hanyalah taladzdzudz (pemuas syahwat/bersenang-senang) dan pendapat yang menurutkan keinginan hawa nafsu. ${ }^{3}$

Para ulama pendukung dan pengguna istibsan tidak sependapat dengan Imam Syafii. Menurut mereka, istibsan bukanlah talad₹drudz atau pendapat yang didasarkan atas keinginan hawa nafsu, tetapi pendapat yang didasarkan atas dalil yang kuat yang bisa dipertanggungjawabkan. Dr. Umar Sulaiman Abdullah al-Asyqar mengatakan, "Sesungguhnya

\footnotetext{
${ }^{1}$ Abdul Karim Zaidan, Al-Wajiz fi Usûl al-Figh, Muassasah ar-Risalah, Beirut, Cetakan Kelima, 1996, hlm. 234.

2 Chaerul Umam, dkk., Usûl Fiqh 1, Pustaka Setia, Bandung, Cetakan Kedua, 2000, hlm., 131 .

3 Abdul Karim Zaidan, loc.cit.
} 
istihsan bukanlah pendapat yang didasarkan kepada hawa nafsu atau bersenang-senang. Istibsan adalah tarjï (pengutamaan) atas suatu dalil atas dalil yang lain. ${ }^{4}$ Menurut Syekh Muhammad al-Khudhari, bagi kalangan Hanafiyah, istibsan bukanlah sebagaimana diperkirakan oleh para penentangnya bahwa ia semata-mata pendapat tanpa dalil atau pendapat hawa nafsu dan syahwat. Istibsan adalah qiyas yang berlawanan dengan qiyas yang lain yang ditarjih karena adanya dalil yang kuat. ${ }^{5}$ Asy-Syathibi lebih tegas mengatakan, "Sesungguhnya orang yang mempergunakan istihsan tidaklah merujuk kepada perasaan dan hawa nafsunya, tetapi ia merujuk kepada maksud Syarî (pembuat syariat) yang sudah diketahui secara global. ${ }^{6}$

Perbedaan pandangan terhadap kehujahan istibsan sebagai dalil syarâ berimplikasi kepada perbedaan penetapan hukum. Dalam masalah zakat, misalnya, para ulama sepakat bahwa membayar zakat harus disertai dengan niat untuk memisahkan ukuran yang wajib dizakati. Namun, mereka berbeda pendapat dalam hal menzakatkan atau menyedekahkan seluruh harta tanpa niat zakat. Apakah kewajiban zakat yang bersangkutan sudah gugur atau masih memiliki tanggungan sampai ia meniatkan zakat yang diberikan. Syafiiyah dan sebagian ulama mazhab Hanbali yang menentang istibsan berpendapat, kewajiban itu tidak gugur. Jika seseorang menyedekahkan atau menzakatkan seluruh hartanya tanpa niat zakat, kewajibannya membayar zakat belum gugur. Abu Hanifah r.a. dan pengikutnya yang menggunakan istibsan berpendapat, kewajiban zakat tersebut telah gugur.?

Karena perbedaan pendapat mengenai istibsan berimplikasi terhadap hukum yang di-istimbath, kajian terhadap masalah ini menjadi menarik. Di dalam tulisan ini akan dibahas pengertian istibsan, kehujahan istibsan dan argumentasinya, bentukbentuk istibsan, dan penerapan istibsan dalam istimbath hukum.

\footnotetext{
${ }^{4}$ Umar Sulaiman Abdullah al-Asyqar, Nazariyat Fi Usâl al-Fiqh, Dar an-Nafâis, Oman, Cetakan Kedua, 2004, hlm. 248.

5 Muhammad al-Khudhary, Usûl al-Fiqh, Dâr al-Hadîs, Kairo, 2003, hal. 329.

${ }^{6}$ Umar Sulaiman Abdullah al-Asyqar, loc. cit.

7 Rachmat Syafie'i, Ilmu Ushul Fiqih, Pustaka setia, Bandung, Cetakan Pertama, 1999, hlm. 114.
}

\section{Pengertian Istihsan}

Secara etimologis, istihsan berasal dari kata kerja bahasa Arab istahsana yastahsinu istihsanan yang berarti “mencari kebaikan” atau عد الشيئ حسنا (menganggap baik sesuatu), ${ }^{8}$ baik fisik, nilai, maupun keduanya. Ia merupakan bentukan dari kata hasuna yabsunu busnan atau hasanan yang berarti "baik" atau "bagus".

Secara terminologis, Al-Bazdawi (400-482 H/1010-1070 M), ulama ahli Ushul Fiqh mazhab Hanafi, mengatakan:

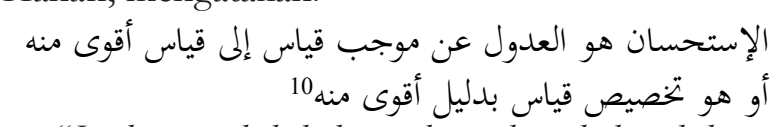

"Istihsan adalah berpaling dari kehendak qiyas kepada qiyas yang lebih kuat atau pengkhususan qiyas karena ada dalil yang lebih kuat daripadanya".

Definisi ini sejalan dengan definisi yang diberikan al-Halwani al-Hanafi, yang juga bermazhab Hanafi. Menurutnya:

$$
\text { الإستحسان: ترك القياس لدليل أقوى منه من كتاب أو سنة أو }
$$

"Istihsan adalah meninggalkan qiyas karena ada dalil yang lebih kuat dari padanya, baik dalil Alquran, sunah, maupun ijmak”.

Sebagian ulama Hanabilah mengatakan:

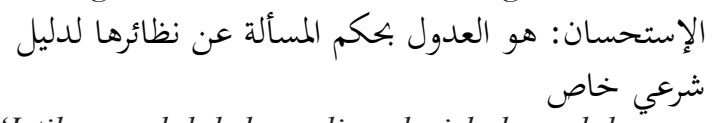

"Istihsan adalah berpaling dari hukum dalam suatu masalah disebabkan adanya dalil syarâ yang khusus". ${ }^{12}$

Menurut al-Kurkhi al-Hanafi, istihsan adalah "keputusan hukum seorang mujtahid terhadap suatu permasalahan berbanding terbalik dari hukum permasalahan lain yang sejenis, ditimbang dari sisi yang lebih kuat yang menuntut perubahan dari hukum awalnya." "13

Ada pula ulama yang mengatakan bahwa istibsan adalah "meninggalkan hukum yang menggunakan dalil nas dan menggantinya dengan hukum kebiasaan demi kemaslahatan manusia."14

\footnotetext{
8 Abdul Karim Zaidan, op. cit., hlm. 230.

9 Mahmud Yunus, Kamus Bahasa Arab-Indonesia, PT Hidakarya Agung, Jakarta, Cetakan Kedelapan, 1990., hlm. 102.

${ }^{10}$ Abdul Karim Zaidan, loc. cit.

${ }^{11}$ Ibid.

${ }^{12}$ Ibid. hlm. 231.

${ }^{13}$ Muhammad Abu Zahrah, Ushôl al-Fiqh, Dâr al-Fikr alArabi, Kairo, 2004, hlm. 238.

${ }^{14}$ Abdul Halim Hakim, Al-Bayân fi Tlmi Ushûl al-Fiqh, Darussalam Press, Gontor, t.th., vol. III, hlm. 41. lihat juga Prof. Dr. H. Rachmat Syafe'i, MA, op.cit., hlm. 112.
} 
Bagi ulama Malikiyah teori istibsan merupakan salah satu teori dalam mencapai kemaslahatan yang merupakan tujuan syarâ dalam menetapkan hukum. ${ }^{15}$ Ibn Arabi al-Maliki mendefinisikan istibsan sebagai berikut:

$$
\text { الاستحسان ترك مقتضى الدليل على طريق الاستثناء و }
$$

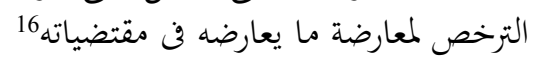

"Istihsan adalah meninggalkan suatu dalil dengan menggunakan metode pengecualian dan rukhsah dikarenakan ada hal yang bertentangan dalam pelaksanaan dalil tersebut."

Imam al-Ghazali dalam kitabnya al-Musthasfâ vol. I, hal. 137 mengatakan bahwa istihsan adalah semua hal yang dianggap baik oleh mujtahid menurut akalnya.

Definisi yang lebih jelas dan mudah difahami dikemukakan oleh Prof. Dr. Mukhtar Yahya dan Prof. Drs. Fatchurrahman. Menurutnya, "istibsan adalah meninggalkan qiyas yang nyata untuk menjalankan qiyas yang tidak nyata (samar-samar) atau meninggalkan hukum kulli untuk menjalankan hukum istisnâi (pengecualian) disebabkan ada dalil yang menurut logika membenarkannya." ${ }^{17}$

Definisi terakhir ini menegaskan bahwa istibsan menyangkut salah satu dari dua hal. Pertama, meninggalkan qiyas jali (nyata) untuk menggunakan qiyas khafi (samar), atau kedua, meninggalkan hukum kulli untuk menggunakan hukum istisnâi. Semua itu dilakukan karena ada dalil yang mendukung. Dalil tersebut bersifat logis dan bisa dipertanggungjawabkan secara hukum.

Dari keseluruhan definisi di atas terlihat bahwa istibsan terkait dengan dua hal penting. Pertama, qiyas. Dengan adanya qiyas maka persoalan istibsan muncul. Kedua, maslahat manusia. Dengan tujuan inilah Imam Abu Hanifah mengonsep istibsan sebagai metode ijtihad. Karena itu, istibsan dalam mayoritas penggunaan hampir tidak lepas dari qiyas dan maslahat, walaupun dalam pembagiannya ada beberapa ulama yang mengaitkan istibsan dengan sumber hukum lainnya seperti Alquran, sunah, dan ijmak.

\section{Kehujjahan Istihsan}

Sebagaimana dikemukakan di atas, istibsan adalah dalil syarâ yang diperselisihkan (mukhtalaf fỉh).

\footnotetext{
15 Chaerul Umam, dkk., op. cit., hlm. 119.

${ }^{16}$ Umar Sulaiman Abdullah al-Asyqar, op. cit., hlm. 247.

${ }^{17}$ Mukhtar Yahya dan Prof. Drs. Fatchurrahman, DasarDasar Pembinaan Hukum Fiqh Islami, PT Al-Mâarif, Bandung, 1986, hlm. 100.
}

Karena itu, para ulama berbeda pendapat mengenai kehujjahannya. Secara garis besar mereka terbagi kepada dua golongan. Pertama, ulama-ulama yang memperbolehkan penggunaan istibsan. Mereka adalah ulama-ulama Hanafiyah, Malikiyah dan sebagian Hanabilah. Kedua, ulama-ulama yang tidak menyetujui penggunaan istibsan. Mereka adalah ulama-ulama Syafiiyah, Zhahiriyah, Muktazilah, dan Syiah, terutama Syiah Koptik.

Golongan pertama dipimpin oleh ulama Hanafiyah, seperti diriwayatkan oleh Imam Muhammad bin Hasan r.a. bahwa tidak ada larangan bagi seorang mujtahid menggunakan istibsan dalam menentukan hukum suatu permasalahan tertentu. Pendapat ini disepakati oleh ulama Malikiyah seperti diriwayatkan oleh Imam Malik r.a. sendiri dan Asba' bin Faraj bahwa penggunaan istibsan oleh mazhab Maliki lebih dominan daripada qiyas dalam permasalahan fikih. Begitu pula ulama Hanabilah seperti yang diriwayatkan oleh Jalal adDin al-Mahally dan disepakati oleh al-'Athar dalam basyizah-nya yang dinukil dari Imam al-Amidi dan Ibnu Hajib. Alasan yang mereka kemukakan adalah: 1. Firman Allah swt. dalam surat az-Zumar (39) ayat 17 :

$$
\text { الذين يستمعون القول فيتبعون أحسنه }
$$

"Mereka yang mendengarkan perkataan lalu mengikuti apa yang paling baik di antaranya"

Menurut mereka, ayat ini menunjukkan keutamaan dan keharusan untuk mengikuti yang baik. Keutamaan dan keharusan merupakan pertanda hujjiyyah /dasar hukum. Karena itu, penggunaan istibsan sebagai dasar hukum dibolehkan.

2. Firman Allah swt. dalam surat az-Zumar (39) ayat 55:

$$
\begin{aligned}
& \text { “Dan ikutilah sebaik-baik apa yang telah } \\
& \text { diturunkan kepadamu dari Tuhanmu”. }
\end{aligned}
$$

Ayat ini menunjukkan bahwa Allah swt. memuji golongan manusia yang apabila dihadapkan kepada mereka perkara-perkara yang baik dan lebih baik, mereka memilih perkara yang lebih baik.

3. Hadis riwayat Abdullah bin Mas'ud r.a.:

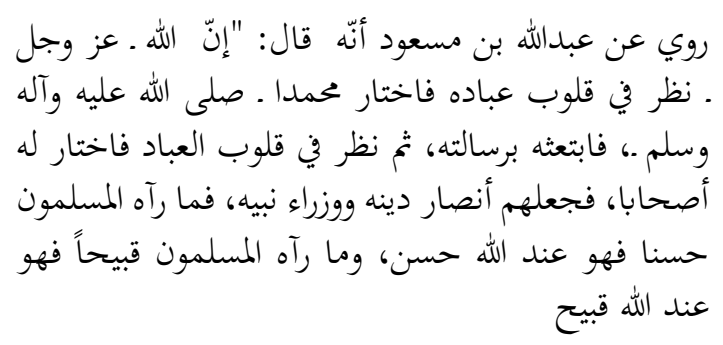


Diriwayatkan dari Abdullah bin Mas'ud, ia berkata,

"Sesungguhnya Allah azza wa jalla melihat ke dalam hati hamba-hamba-Nya. Kemudian Ia memilih Muhammad s.a.w. untuk diutus menyebarkan ajaran-Nya. Lalu ia melihat ke dalam hati hamba-hamba-Nya, kemudian memilih para sahabat dan menjadikan mereka penolong agama-Nya dan pendamping NabiNya. Karena itu, apa yang dipandang oleh kaum muslimin baik, bagi Allah juga baik, dan apa yang dilihat oleh mereka jelek, bagi Allah juga jelek."

(Hadis riwayat Hakim dan Baihaqi)

Perkataan Abdullah bin Masûd di atas menunjukkan bahwa apa yang dipandang oleh mayoritas kaum muslimin baik adalah baik juga bagi Allah swt. Begitu pula sebaliknya; apa yang dilihat oleh kaum muslimin jelek, jelek pula bagi Allah swt. Kata hasanan (baik) dalam kalimat pada riwayat tersebut merupakan suatu istilah yang kemudian dalam ilmu fiqih berubah menjadi istibsan.

Meskipun kehujjahan hadis ini diperdebatkan oleh para ulama karena statusnya yang mauquf sampai ke Abdullah bin Masûd saja namun para ulama Hanafiyah menjadikannya sebagai salah satu alasan untuk membenarkan istibsan sebagai dalil syarâ.

4. Ijmak para ulama yang diterapkan di masyarakat. Misalnya, kebiasaan tidak membayar saat masuk kamar mandi umum dan meminum air di tempat umum yang telah disediakan. Kebiasaan tersebut menunjukkan kebolehan. Masalah ini disebut sebagai ijmak atau kebiasaan umum ('urf 'am) dengan mengesampingkan qiyas.

Meskipun para ulama yang menggunakan qiyas mempunyai beberapa argumen untuk membenarkan pendapat mereka, ulama-ulama yang menolak tetap tidak setuju karena mereka menilai landasan istihsan tersebut tidak jelas, bahkan mereka menganggap penggunaan istibsan sebagai perbuatan yang batil.

Imam Syafii r.a. mengatakan, dalam berijtihad seseorang harus memiliki landasan yang jelas; seperti berijtihad untuk menentukan arah kiblat bagi orang yang tidak mengetahui arah kiblat harus didasarkan kepada landasan yang kuat. Ketidaktahuan arah kiblat tidak memberikan legalitas bagi seseorang untuk menentukan apa yang dianggap baik tanpa dasar, walaupun seseorang harus tetap berijtihad dalam kondisi seperti ini. Dikatakannya, "Hal ini (penentuan arah kiblat) tidak menandakan kebolehan bagi seseorang untuk mengatakan atau melakukan perbuatan yang dianggapnya baik (istibsan)." "18 Menurut ulama lain, dalam kondisi seperti ini bisa digunakan istibsan dan masalah ini merupakan permasalahan istibsan.

Imam Syafii r.a., mengibaratkan Istibsan sebagai meninggalkan dalil yang telah ditetapkan syarâ yang mengarah kepada suatu hukum tertentu, dan usaha untuk sampai kepada suatu hukum dengan jalan lain dari yang telah digariskan syariat untuk hukum tersebut. Di dalam kitab Al-Umm, secara eksplisit ia menguraikan dengan panjang lebar pandangannya tentang istihsan yang dianggapnya batil. Uraian itu termuat di dalam bab khusus berjudul "Kitab Ibthal al-Istibsan (Kitab Pembatalan Istibsan)." Ringkasan dari uraian tersebut adalah sebagai berikut:

1. Kalau istibsan dipergunakan untuk mendukung nas, ia tidak diperlukan; sedangkan apabila istibsan tidak berdasarkan nas atau keluar dari nas, tidak ada kebaikan di dalamnya (tidak boleh dipergunakan).

2. Istibsan bukanlah nas, bukan pula merujuk kepada nas, tetapi hanya mengikuti hawa nafsu.

3. Rasulullah s.a.w. tidak memberi pendapat dalam banyak permasalahan yang tidak ada hukumnya. Beliau tidak berfatwa apa yang baik bagi dirinya (istihsan) [tetapi menunggu wahyu dari Allah swt sebelum berpendapat, pen.]. Andaikata istibsan dibolehkan, tentu akan menjadi hujjah bagi Nabi s.a.w. dan beliau akan berfatwa menggunakan istibsan tanpa menunggu wahyu dari Allah swt.

4. Rasululah s.a.w. mengingkari pendapat sebagian sahabat yang menggunakan istihsan dalam beberapa permasalahan. Salah satu di antaranya adalah Nabi Muhammad s.a.w. melarang para sahabat membunuh orang kafir yang berkata, "أسلمت تحت حر السيف". Peristiwa itu terjadi ketika seorang sahabat membunuh seorang kafir. Pada saat akan dibunuh orang kafir itu menyatakan masuk Islam, namun sahabat tersebut tetap membunuhnya. Ia berpendapat, alasan orang kafir itu masuk Islam adalah karena takut dibunuh, bukan benar-benar karena

${ }^{18}$ Zainal Abidin al-'Abd Muhammad Nur, Ra'yu Ushuliyyîn fi Mashâlih al-Mursalah wa al-Istihsân, Dar al-Buhuts li adDirasah al-Islamiyah wa Ihyâat-Turats, U.A.E, 2004, vol. II, hlm. 33. lihat juga Imam Syafii, Al-Risâlah, hal. 503. 
mau menjadi muslim.

5. Istihsan tidak memiliki kekuatan (rujukan/ pedoman). Hal ini menyebabkan adanya beberapa fatwa dalam suatu masalah tanpa ada pendapat yang rajih. Akibatnya, terjadi perbedaan-perbedaan pendapat (perselisihan).

6. Kalau istibsan diperbolehkan bagi para mujtahid tanpa nas atau qiyas, selain mujtahid tentu boleh pula mengeluarkan hukum berdasarkan akalnya. Dengan demikian, tidak ada perbedaan antara mujtahid dan selain mujtahid. Menurut Imam Syafii r.a., apabila setiap mufti atau hakim boleh menggunakan istihsan dalam berfatwa dan menentukan hukum tertentu, para intelektual dan cendikiawan yang tidak memahami ilmu syariat pun boleh juga menentukan suatu hukum dengan alasan demi kemaslahatan manusia. ${ }^{19}$

Di samping beberapa hal di atas, para ulama yang menolak penggunaan Istibsan juga menggunakan dalil Alquran antara lain:

1. Firman Allah swt. dalam surat al-Qiyamah ayat 36:

$$
\text { أيحسب الإنسان أن يترك سدى }
$$

"Apakah manusia mengira akan ditinggalkan secara sia-sia?”

Jawaban terhadap pertanyaan ini tentunya, "tidak". Artinya, manusia tidak akan ditinggalkan secara sia-sia. Term " di di dalam ayat tersebut bermakna segala sesuatu yang tidak disuruh dan tidak dilarang (sia-sia), seperti yang dikemukakan Imam Syafii r.a. dan diriwayatkan oleh ijmak ulama Syafîyah. Ayat ini menegaskan bahwa Allah swt. tidak meninggalkan perkara-perkara dunia sia-sia tanpa hukum yang jelas dan landasan yang kuat. Istihsan dalam pandangan ulama yang menolaknya adalah hukum tanpa dalil syarâ yang termasuk kategori sesuatu yang tidak diperintahkan dan tidak dilarang atau merupakan perbuatan sia-sia. Di dalam kitab Al-Umm Imam Syafii r.a. mengatakan,

"Para ulama tidak berbeda dalam memahami kata 'sia-sia', yang berarti sesuatu yang tidak disuruh dan tidak dilarang. Barangsiapa memberikan fatwa atau memberikan hukum apa yang tidak disuruh, ia telah membolehkan bagi dirinya

${ }^{19}$ Umar Sulaiman al-Asyqar, op. cit., hlm. 244, Lihat pula Muhammad bin Idris asy-Syafii , Al-Umm, Dar al-Kutub al-Ilmiyah, Beirut, Cetakan Pertama, 2002, Jilid 7, hlm. 267-277. melakukan pekerjaan yang sia-sia; sedangkan Allah swt. telah mengajari bahwa Ia tidak akan meninggalkan manusia dengan sia-sia." 20

2. Firman Allah swt. dalam surat an-Nisa ayat 59:

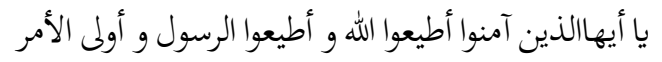

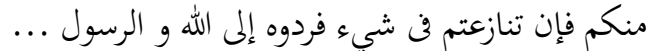

"Wahai orang-orang yang beriman, taatlah kepada Allah, taatlah kepada Rasul dan para pemimpin kamu. Apabila kamu berselisih dalam suatu perkara maka kembalikanlah kepada Allah dan Rasul...."

Ayat ini memerintahkan orang-orang yang beriman untuk menaati Allah swt. dan Rasul-Nya, melarang mengikuti hawa nafsu, dan memerintahkan untuk kembali kepada Alquran dan sunah ketika terjadi perselisihan. Dengan demikian, jika ada perbedaan pendapat mengenai sesuatu harus diselesaikan dengan tetap merujuk kepada Alquran dan sunah sebagai dasar, bukan menggunakan istihsan karena istihsan tidak didasarkan kepada dalil yang diambil dari syarâ. Istihsan adalah dalil yang batil.

Dari penjelasan di atas dapat diketahui bahwa hukum istihsan menurut Imam Syafii r.a. adalah batil atau mabdzur syar'an, karena ia merupakan perkataan tanpa dalil dan orang yang menggunakan istibsan dalam berijtihad termasuk orang yang mengerjakan perbuatan yang batil.

\section{Analisis Terhadap Perbedaan Pendapat Tentang Istihsan}

Apabila diperhatikan perbedaan pendapat ulama mengenai penggunaan istibsan sebagai dalil syarâ terlihat bahwa perbedaan itu terjadi karena perbedaan mereka memberikan definisi terhadap istibsan. Syekh Muhammad al-Khudari dalam karyanya Ushul Fiqh mengatakan, istibsan menurut ulama Hanafiyah bukan seperti yang diprediksikan penyanggah-penyanggahnya dari ulama-ulama yang menolak pendapat tersebut; sebagai perkataan tanpa dalil dan perkataan yang mempergunakan hawa nafsu dan syahwat saja. Istihsan yang dipakai oleh ulama-ulama Hanafiyah, Malikiyah dan Hanabilah adalah qiyâs yang menyanggah qiyâs lainnya.

Ulama Hanafiyah sendiri menolak istilah istihsan dalam makna lain yaitu setiap dalil yang bertentangan dengan qiyâs zahir, apabila hal tersebut mengarah kepada kepentingan suatu pihak saja.

${ }^{20}$ Muhammad Zakaria al-Bardisi, Usûl Figh, Dar atsTsaqâfah, Kairo, 1996, hlm. 330. lihat juga ibid., hal. 39-40. lebih lengkap lihat Muhammad bin Idris asy-Syafii, Al-Umm, op. cit., hlm. 273. 
Dalam konteks ini, Imam Ghazali dari Syafiiyah mengatakan, "Ini (wujud istibsan) adalah hal yang tidak diingkari oleh semua ulama, akan tetapi pengingkaran terletak pada lafaz dan pengkhususan jenis dalil ini dan penamaannya sebagai istibsan."21

Perkataan Imam Syafii r.a. yang menyatakan bahwa orang yang menggunakan istibsan telah membuat syariat baru mengandung makna bahwa barangsiapa menggunakan istibsan dengan mengikuti hawa nafsunya sendiri maka seakan-akan ia menjadi seorang nabi yang memiliki syariat.

Jika dicermati lebih jauh, apabila istibsan dimaknai sebagai seorang mujtahid mengambil yang terbaik dari beberapa nas atau dari beberapa qiyas atas nas tersebut karena ketiadaan nas, hal ini tidak ditentang oleh Imam Syafii, seperti yang diuraikan di dalam Kitab Pembatalan Istihsan. Bahkan dengan makna seperti ini, Imam Syafii dalam berbagai kesempatan juga menggunakan istibsan untuk menqistimbath hukum berbagai masalah, walaupun, tentu saja, Imam Syafii tidak menyebutnya sebagai istibsan karena ia dengan tegas menolak istibsan. Imam Syafii menyebutnya qiyas. Baginya, semua persoalan hukum yang tidak termuat secara eksplisit di dalam Alquran dan sunah dapat diselesaikan dengan qiyas.

Di antara contoh istimbath hukum Imam Syafii yang sejalan dengan teori istibsan adalah:

1. menentukan nilai mut'ah yaitu sebanyak 30 dirham;

membatasi waktu syuf'ah (hak prioritas pembelian) dengan berpendapat bahwa waktu syuf'ah bagi pemegang hak prioritas (syafi) adalah tiga hari.

Imam Ahmad bin Hanbal juga menggunakan istibsan dengan pengertian ini. Menurut Ibn Taimiyyah, di dalam riwayat al-Maimuni, Imam Ahmad menggunakan istihsan ketika berpendapat bahwa setiap orang harus bertayammum pada setiap kali akan shalat sampai batal atau mendapat air, padahal qiyasnya adalah hanya sekali seperti wudu dengan air. ${ }^{22}$

Pandangan-pandangan dan praktek istimbath hukum yang pernah dilakukan oleh Imam Syafii dan Imam Ahmad bin Hanbal sebagaimana dikemukakan di atas menunjukkan bahwa kedua imam besar ini tidak menolak istibsan secara a priori

\footnotetext{
${ }^{21}$ Muhammad al-Khudhari, Ushûl al-Fiqh, Dâr al-Hadîs, Kairo, 2003, hal. 330.

${ }^{22}$ Umar Sulaiman al-Asyqar, op. cit., 245.
}

sepanjang istibsan dimaknai sebagai pengambilan yang terbaik dengan dasar dan landasan yang kuat, bukan didasarkan kepada kemauan atau kehendak hawa nafsu semata. Dengan kata lain, istibsan yang ditolak oleh kedua Imam tersebut adalah istibsan yang hanya berorientasi kepada sesuatu yang dianggap baik tanpa dilandasi oleh nas atau dalil syariat, tetapi semata-mata hanya untuk memuaskan nafsu dan talad₹dzudz (bersenang-senang).

Jika demikian pandangan Imam Syafii dan Imam Ahmad bin Hanbal berarti secara substantif tidak ada perbedaan mendasar antara kedua Imam tersebut dengan Imam Hanafi dan para ulama yang menggunakan istibsan. Dalam pandangan Imam Hanafi, Istibsan bukanlah untuk memuaskan hawa nafsu dan tanpa dalil, tetapi menarjih suatu dalil dengan dalil yang lain. Karena itu, di dalam pembahasan definisi istihsan, Imam Syatibi menambahkan, "Orang yang menggunakan istibsan tidak boleh hanya berdasarkan keinginan dan menurutkan hawa nafsunya semata. Ia harus memiliki ilmu dan pemahaman mengenai maqasid syariah (tujuan syariat) dalam konteks yang lebih luas." 23

\section{Penerapan Istihsan Sebagai Dalil Syarâ}

Sebagaimana perbedaan ulama di dalam memberikan definisi dan kedudukan bujjiyyah istibsan, mereka juga berbeda pendapat dalam penerapan istihsan sebagai dalil syarâ. Secara umum, mereka terbagi kepada dua golongan: ${ }^{24}$ Pertama, ulama yang menggunakan istibsan secara mutlak tanpa mempersoalkan apakah maslahat yang terdapat di dalamnya merupakan maslahat dharuriyyah (primer), bajjiyyah (sekunder), atau tabsiniyyah (tersier). Ulama yang masuk ke dalam golongan ini adalah ulama-ulama Hanafiyah, Malikiyah, dan sebagian Hanabilah dalam ruang lingkup yang lebih luas.

Yang dimaksud dengan dharuriyyah (skala primer) adalah sesuatu yang menjadi ketergantungan manusia baik itu di dunia maupun di akhirat; bajjiyyah (skala sekunder) adalah suatu hal yang dianggap maslahat dan dibutuhkan oleh manusia serta berfungsi untuk memudahkan sesuatu yang sulit; dan tabsiniyyah (skala tersier) adalah mengambil kebiasaan yang baik dan melaksanakan kemuliaan

\footnotetext{
${ }^{23}$ Ibid., hlm. 248

${ }^{24}$ Zainal Abidin al-'Abd Muhammad Nur, op.cit., hlm. 171180.
} 
akhlak. ${ }^{25}$ Ketiga skala tersebut merupakan pembagian maqashid asy-syariah ditinjau dari segi pengaruhnya terhadap masyarakat.

Menurut teori maqasid asy-syariah, setiap maslahat umat harus terus dijaga karena ia adalah tujuan diturunkannya syariat Islam. Dalam kaitan antara mashlahab dam maqashid, dapat dijelaskan bahwa maqashid syariah adalah mashalib yang dikembalikan terhadap manusia di dunia dan di akhirat, baik dengan cara mengambil manfaat atau menolak mudarat. Maqashid asy-syariah mengandung mashlabahbagi manusia. Dalam kaidahnya, maqashid asy-syariah harus berdasarkan mashlahah, tapi tidak semua mashlabah merupakan maqashid. Karenanya, mashlahah tidak boleh bertentangan dengan nash syar'i. Jika terjadi pertentangan, hal itu tidak bisa dinamakan masblabah.

Pendapat Hanafiyah, Malikiyah, dan sebagian Hanabilah sebagaimana disebutkan di atas ditegaskan oleh Imam al-Qarafy dalam bukunya Syarah al-Mahshul yang menolak pendapat Imam arRazy mengenai pembatasan maslahat dengan dalil perkataan dan perbuatan para sahabat yang tidak membatasi jenis maslahat dalam berijtihad. ${ }^{26} \mathrm{Ibn}$ alArabi dari kalangan Malikiyah menyatakan, "Istibsan yang digunakan oleh Imam Malik r.a. dikhususkan untuk maslahat." ${ }^{27}$ Ungkapan ini menunjukkan bahwa maslahat yang dimaksud bersifat mutlak tanpa perincian primer, sekunder, maupun tersier. Penggunaan ini terlihat antara lain dalam penafsiran surat al-Baqarah ayat 233:

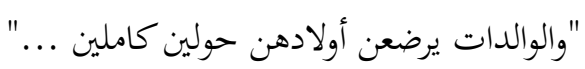

Para ibu hendaklah menyusukan anak-anaknya selama dua tahun penuh,...

Menurut Imam Malik r.a., bagi seorang ibu yang menyusui anaknya, masa dua tahun seperti yang tercantum dalam ayat di atas masuk dalam kategori maslahat tersier, bukan maslahat primer maupun sekunder yang dalam kasus ini adalah pentingnya susu bagi seorang anak, tanpa perincian masa pemberian susu kepada anak tersebut.

Ibnu Daqiq al-'Ied mengatakan, yang rajih dalam penggunaan istibsan adalah pendapat Imam Malik r.a., kemudian pedapat Imam Ahmad bin

\footnotetext{
${ }^{25}$ Wahbah az-Zuhaili, Ushûl al-Fiqhi al-Islâmî, Dâr al-Fikr, Damaskus, cet.3, 2005, juz 2, hlm. 309-317.

${ }^{26}$ Imam al-Qarafi, Nafâis al-Ushûl fi Syarb al-Mahsul, Maktabah Nubbaz Musthafa al-Baz, Makkah alMukarramah, t.th., vol. III, hlm. 200.

${ }^{27}$ Ibnu Arabi, Abkâm al-Qurân, Dar al-Fikr, Beirut, t.th. vol. II, hlm. 746 .
}

Hanbal r.a. ${ }^{28}$ Beberapa ulama Syafizyah seperti Imam Haramain juga lebih sependapat dengan Imam Malik r.a. dalam masalah ini. Walaupun Mazhab Syafîi mengingkari adanya istihsan, beberapa ulama Syafizyah mengakui penggunaan maslahat. Mereka tidak membedakan dan memilah-milah antarmaslahat tersebut.

Kedua, ulama yang membedakan maslahat, yaitu Imam Syafii dan Imam Ghazali. Meskipun ada beberapa ulama Syafiiyah yang tidak memilahmilahkan maslahat, namun Imam Syafii dan Imam Ghazali memilahkannya. Bagi mereka, jika maslahat masuk dalam bagian primer dan sekunder, boleh digunakan istibsan [tentu yang dimaksud di sini adalah istibsan dalam pengertian yang bisa diterima keduanya] sebagai ijtihad didalamnya, tetapi apabila masuk kategori tersier, istibsan tidak boleh digunakan. Pandangan Imam Syafii mengenai hal ini diutarakan oleh Imam Baidhawi r.a. bahwa hanya maslahat primer yang diperhatikan ketika ada permasalahan, sedangkan maslahat lainnya yang tidak membahayakan manusia tidak boleh digunakan ijtihad apabila sudah ada nas. Imam Haramain, yang mengambil nas dari Imam Syafii r.a., mengatakan, "Imam Syafii r.a. tidak memperbolehkan pengecualian dan berlebihan dalam menentukan hukum suatu maslahat. Ia lebih memilih mengorelasikan hukum-hukum dengan maslahat-maslahat yang menjadi kebutuhan pokok secara umum saja." 29

Pendapat Imam Ghazali mengenai hal ini tertuang di dalam karyanya yang berjudul Syifấ al-Ghalîl dan al-Mustashfâ. Ia menspesifikasikan pengambilan maslahat apabila hanya berada dalam tataran primer seperti yang tercantum dalam Syifấ al-Ghalîlatau primer dan sekunder saja seperti yang tercantum dalam al-Mustashfâ.

Perbedaan pandangan mengenai penerapan maslahat dalam berijtihad, termasuk dalam masalah istibsan, tidak hanya terjadi di kalangan ulama-ulama klasik. Para ulama kontemporer pun berbeda pendapat mengenai hal tersebut. Secara umum mereka terbagi kepada dua kelompok. ${ }^{30}$

Kelompok pertama, golongan yang berlebihan dalam memandang maslahat sampai berpendapat bahwa maslahat dapat membatalkan nas suatu

\footnotetext{
${ }^{28}$ Muhammad bin Yusuf (Abu Hayyan al-Andalusi), AlBabr al-Mubith, Dar al-Kutub al-Ilmiyyah, Beirut, 1993, vol 3, hlm. 240.

${ }^{29}$ Ibid., hal. 241.

${ }^{30}$ Zainal Abidin al-'Abd Muhammad Nur, op.cit., hal 221.
} 
hukum tertentu atau paling tidak maslahat lebih dikedepankan, baru disesuaikan dengan nas. Salah seorang ulama yang berprinsip demikian adalah Abdul Wahhab Khalaf. Ia seorang ulama yang mengedepankan maslahat baru kemudian menyesuaikannya dengan nas. Menurutnya, Nabi Muhammad s.a.w. menggambarkan kepada sahabat-sahabatnya metode yang digunakan dalam menentukan suatu hukum; yaitu mengarahkan mereka terlebih dahulu kepada nas dari Alquran dan sunah kemudian ijtihad sebagai metode alternatif. Namun, ia juga mengatakan bahwa para sahabat kadang-kadang melihat hukum melalui ijtihad mereka yang sesuai dengan maslahat, meskipun berbeda dengan zahir nas dari makna hukum tersebut.

Di samping Abdul Wahhab Khallaf, Syekh Ali Hasballah juga berpendapat demikian. Di dalam bukunya Ushûl Tasyri' ia menjelaskan bahwa maslahat lebih dikedepankan daripada nas. Apabila ada pertentangan antara maslahat dan nas, maslahat harus dikedepankan terlebih dahulu.

Kelompok kedua, golongan yang tetap berpegang pada nas dalam kondisi dan tidak lebih mengutamakan maslahat. Syekh Muhammad Musthafa asy-Syulbi, salah seorang ulama Malikiyah, menjelaskan metode Imam Malik r.a. dalam berijtihad bahwa nas-nas yang ada merupakan intisari yang digunakan manusia untuk menjaga maslahatnya. Oleh sebab itu segala hal yang menjadi maslahat manusia, itulah yang menjadi makna bagi nas tersebut.

Syekh Abdullah bin Baz, mufti Arab Saudi, dalam beberapa fatwanya menjelaskan, maslahat manusialah yang mengikuti nas. Jika terjadi pertentangan di antara keduanya, nas yang sharîh digunakan sebagai hukum yang rajih. Hal ini dapat dilihat dari beberapa pendapatnya tentang haji dan umrah bagi wanita.

Walaupun pada kesimpulan terakhir, para ulama kontemporer lebih banyak menggunakan kaidah la ifrath wa la tafrith fi ad-din (tidak berlebih-lebihan dalam agama dan tidak pula meninggalkan sama sekali). Semuanya disesuaikan dengan situasi dan kondisi dengan lebih mengedepankan kemudahan dan tidak mempersulit dalam menentukan hukum. Metode inilah yang dipakai Dr. Yusuf Qaradhawi dalam berfatwa. ${ }^{31}$

\footnotetext{
${ }^{31}$ Yusuf Qaradhawi, Fatâwâ Mu'ashirah, Dar al-Qalam, Kairo, 2003, vol. 1, hlm. 11.
}

\section{Qiyâs dan Istihsan}

Sebagaimana dikemukakan terdahulu, di samping maslahat, masalah yang berhubungan dengan istihsan adalah qiyas. Keduanya mempunyai hubungan yang sangat erat, bahkan jika diperhatikan keterangan Abdul Wahhab Khallaf dan definisidefinisi istibsan yang ada, terlihat bahwa unsur pembentukan istihsan itu adalah qiyâs jali dan qiyâs khafi. Karena itu, apabila terjadi pertemuan antara istihsan dan qiyâs, dapat dijabarkan menjadi empat bagian, istihsan dua bagian dan qiyâs dua bagian. Dua bagian yang dimiliki oleh istibsan adalah istibsan yang kuat pengaruhnya dan istihsan yang tersembunyi kerusakannya dan terlihat kebenarannya; sedangkan dua bagian yang dimiliki oleh qiyâs adalah qiyâs yang lemah pengaruhnya dan qiyâs yang terlihat kerusakannya dan tersembunyi kebenarannya.

Pertentangan di antara keempat hal tersebut bukanlah hal yang mustahil terjadi. Karenanya, jika pertentangan itu terjadi, cara penggunaan dalil yang tepat adalah sebagai berikut:

1. Bagian pertama dari istihsan.

2. Bagian pertama dari qiyâs.

3. Bagian kedua dari qiyâs.

4. Bagian kedua dari istibsan.

Untuk memperjelas keterangan di atas dapat dikemukakan dalam contoh berikut, yaitu hukum air sisa minuman burung yang buas seperti gagak, rajawali, dan elang. Menurut qiyas, air sisa minuman itu najis, namun menurut istihsan, air itu suci.

Ditinjau dari sudut qiyas, air sisa minuman burung buas itu najis karena sisa minuman burungburung yang diharamkan memakannya sama dengan sisa minuman binatang buas yang juga diharamkan, seperti harimau, singa, dan serigala. Alasannya, hukum sisa minuman dari hewan-hewan tersebut mengikuti hukum dagingnya. Namun, menurut istihsan, sisa minuman burung buas itu suci. Ada perbedaan antara burung buas dengan binatang darat yang buas. Burung-burung buas walaupun diharamkan dagingnya, ludah yang keluar dari perutnya tidak bercampur dengan sisa air bekas yang diminumnya; sedangkan binatang darat yang buas air liurnya bercampur dengan sisa air yang diminumnya. Hal itu terjadi karena burung minum menggunakan paruh yang terbuat dari tulang yang suci dan binatang darat minum menggunakan mulutnya. ${ }^{32}$

${ }^{32}$ Mukhtar Yahya dan Drs. Fatchurrahman, op. cit., hlm. 102. 
Dari contoh di atas, qiyâsjali-nya adalah sisa air yang diminum oleh binatang buas adalah najis. Kata 'buas' identik dengan pemakan daging dan setiap binatang pemakan daging adalah najis. Sedangkan qiyâs khafi-nya adalah sisa air yang diminum burung buas tidak najis sebagaimana sisa minuman manusia. Antara manusia dan burung buas ada kesamaan, yaitu sama-sama makhluk hidup yang haram dimakan dagingnya. Illat yang digunakan adalah bercampurnya ludah yang najis dengan air. Hal itu dapat terjadi pada binatang buas, tetapi tidak terjadi pada burung karena burung menggunakan paruh waktu minum bukan lidah atau mulut seperti binatang buas.

Penetapan hukum suci terhadap air bekas minuman burung buas sebagaiamana diuraikan di atas merupakan bentuk istibsan yang mengedepankan qiyas khafi (samar) atas qiyas jali (jelas/terang). ${ }^{33}$ Bentuk Istibsan semacam ini disebut istibsan qiyas (al-istibsan al-qiyasi).

\section{Bentuk-Bentuk Istihsan}

Sebagai dalil syarâ yang masih diperselisihkan kehujjahannya oleh para ulama, pembagian istibsan tidak terlepas dari perbedaan tersebut. Semuanya dipengaruhi oleh definisi-definisi yang berbeda, juga dalil-dalil yang dipakai dalam pembentukan istibsan.

Ulama Hanafiyah membagi istibsan menjadi dua macam: $:^{34}$

Pertama, al-istibsan al-qiyâsi, yaitu mentarjihkan qiyas yang tidak nyata (samar-samar/khafi) atas qiyas yang nyata (jali) berdasarkan suatu dalil, ${ }^{35}$ seperti contoh di atas. Istibsan dalam bentuk ini terjadi apabila dalam satu permasalahan terdapat dua macam qiyâs, salah satunya zahir disebut qiyâs isthilâbi dan kedua khafi yang memerlukan sandaran kepada asal yang lain. al-istibsan al-qiyâsi, dapat terjadi apabila qiyâs khafi memiliki pengaruh dan implikasi lebih besar dari qiyas jali. Syamsu al-A'immah asSarakbsi mengatakan, "Istibsan sebenarnya adalah dua qijâs yang satu jali akan tetapi memiliki pengaruh yang lemah dinamakan dengan qiyâs dan kedua khafi yang memiliki pengaruh yang besar dinamakan istibsan." " Kemudahan bagi manusia dan menjauhi kesulitan (raf'u al-haraj) merupakan asas dari kuat

\footnotetext{
${ }^{33}$ Zainal Abidin al-'Abd Muhammad Nur, op.cit., hal 328.

${ }^{34}$ Muhammad Abu Zahrah, op.cit., hlm. 242.

${ }^{35}$ Mukhtar Yahya dan Prof. Drs. Fatchurrahman, op. cit., hlm. 101.

${ }^{36}$ Ibid., hlm. 240.
}

atau lemahnya pengaruh qiyâs tersebut. Dua hal ini pula yang menjadi asas al-istibsan al-qiyâasi.

Contoh lain dari al-istihsan al-qiyâsi adalah masalah aurat wanita. Pada dasarnya aurat wanita yang tidak boleh dilihat oleh yang bukan muhrim meliputi seluruh tubuhnya kecuali muka dan telapak tangan, tetapi dokter diperbolehkan melihat bagian-bagian lain dari tubuh wanita tersebut untuk keperluan medis. Dalam hal ini ada dua qiyâs yang dipakai. Pertama, ketetapan syariat tentang aurat wanita dan keharaman melihat aurat tersebut. Kedua, kebolehan wanita yang berpenyakit membuka aurat yang diperlukan bagi dokter untuk pengobatannya. Illat dari kebolehan tersebut adalah menjauhi kesulitan.

Kedua, yang menjadi illat bukan kuat atau lemahnya pengaruh qiyâs, tetapi ada pengaruh luar yang berperan di dalamnya. Istibsan dalam bentuk ini terbagi kepada tiga macam:

1. Istibsan sunah, yaitu apabila ada ketetapan dari sunah yang mewajibkan untuk menolak qiyâs. Misalnya, sahnya puasa seseorang yang makan atau minum dalam keadaan lupa. Keadaan ini diqiyaskan oleh para ulama dengan seseorang yang berbuka di tengah hari. Akan tetapi ulama Hanafiyah menolak qiyâs ini dan menggunakan istibsan sunah untuk mengesahkan puasa yang bersangkutan.

2. Istibsan ijmak, yaitu meninggalkan qiyâs pada permasalahan yang telah menjadi ijmak walaupun memiliki hukum yang berbeda dengan qiyâs tersebut. Misalnya, kebolehan jual beli secara salam (jual beli dengan pembayaran terlebih dahulu, barang yang dibeli dikirim kemudian) dan istishnâ (memesan untuk dibuatkan sesuatu yang belum ada atau jual beli secara inden). Jika menggunakan qiyâs maka akad itu batil, karena barang tidak ada di tempat ketika pelaksanaan akad. Akan tetapi karena akad semacam ini sering dilakukan orang dan sudah menjadi kebiasaan maka akad itu dinyatakan sah. Illat yang dijadikan argumen di dalam kasus ini ijmak atau kebiasaan, sehingga qiyâs yang ada dapat ditinggalkan. Istihsan ijmak dapat juga disebut istibsan 'urf. Istibsan ini digunakan untuk menghindari kesulitan menentukan hukum ketika berhadapan dengan kebiasaan umum.

3. Istihsan dharûrah, yaitu apabila dalam suatu permasalahan terdapat bahaya yang dapat mengancam. Misalnya, tidak melakukan 
pembersihan terhadap air di dalam sumur atau telaga yang terkena najis dan menetapkannya suci karena kesulitan melakukan pembersihan itu dan membahayakan. Apabila qiyâs yang digunakan dengan mengiaskannya kepada tempat air lain yang dapat dibersihkan, air di dalam sumur itu bisa saja dibersihkan; dan jika tidak dibersihkan air itu akan terus bernajis sehingga tidak dapat dipakai untuk bersuci. Namun, dengan menggunakan istibsan, air tersebut dihukumkan suci tanpa harus dibersihkan dari najis karena kesulitan melakukan pembersihannya dan membahayakan. Hal tersebut disepakati oleh jumhur ulama dalam menentukan kesucian air dilihat dari banyak atau sedikitnya air itu.

\section{Implikasi Istihsan dalam Penetapan Hukum}

Meskipun ada titik persamaan antara ulama pendukung dan penentang istibsan dalam beberapa hal namun perbedaan mereka tetap lebih menonjol. Perbedaan tersebut melahirkan perbedaan hukum yang mereka tetapkan. Berikut beberapa contoh perbedaan tersebut.

1. Para ulama sepakat bahwa zakat yang dikeluarkan oleh muqakki (orang yang berzakat) harus disertai dengan niat. Zakat tidak sah tanpa niat untuk memisahkan antara harta yang dizakati dan zakat yang dikeluarkan. Akan tetapi mereka berbeda pendapat dalam hal menzakatkan seluruh harta tanpa niat zakat. Apakah kewajiban zakat yang bersangkutan sudah gugur atau muzakki masih memiliki tanggungan sampai dia meniatkan zakat yang dikeluarkan?

Imam Hanafi dan pengikutnya berpendapat, kewajiban zakat tersebut telah gugur sehingga muzake $i$ tidak perlu mengeluarkan zakat lagi. Di dalam kitab Al-Hidayah dikatakan, barangsiapa berzakat dengan seluruh hartanya, tetapi ia tidak menyertainya dengan niat zakat, gugurlah kewajibannya. Pendapat ini didasarkan atas istihsan. Penggunaan dalil istibsan terhadap zakat tanpa niat tersebut adalah apabila nisab zakat harta sudah tercapai. Jika sesuatu sudah ditentukan, tidak perlu penentuan lagi karena ketentuan tersebut hanyalah untuk menyatakan kewajiban. ${ }^{37}$

Mazhab Syafîi dan Hanbali berpendapat, kewajiban itu tidak gugur. Dalam kitab $A l$ Majmu' karya Imam Nawawi r.a. dikatakan, jika seseorang menzakatkan seluruh hartanya tanpa disertai dengan niat zakat, kewajiban zakat tersebut tidak gugur. Argumentasi yang dikemukakan adalah bahwa dalam melaksanakan pekerjaan yang wajib, niat merupakan syarat yang harus dipenuhi. Jika seseorang menzakatkkan seluruh hartanya tanpa berniat untuk menggugurkan kewajibannya (niat zakat) maka kewajiban zakatnya tidak gugur. Hal ini sama dengan orang yang shalat atau melaksanakan ibadah puasa wajib tanpa disertai dengan niat. Ibnu Quddamah dalam kitabnya Al-Mughni mengatakan, hukum seseorang menyedekahkan semua hartanya adalah sunah. Jika tidak berniat zakat, ia tidak mendapat pahala zakat dan tidak gugur kewajiban zakatnya tersebut.

2. Para ulama berbeda pendapat mengenai syarat muamalat yang telah ditetapkan oleh kebiasaan manusia, seperti garansi yang ditetapkan bagi pembeli barang sesuai kesepakatan kedua belah pihak. Ulama-ulama Hanafiyah dan Malikiyah berpendapat, syarat muamalat yang telah ditetapkan kebiasaan manusia adalah sah hukum akad dan syaratnya. Dalam hal ini mereka menggunakan istibsan untuk menganulir qiyas yang mengharuskan akad jual beli tanpa ada syarat tertentu, walaupun dalam hadis Rasulullah sendiri ada dalil yang melarang mengumpulkan syarat dan jual beli dalam satu akad. Ulama Malikiyah bahkan lebih jauh lagi, menganggap sah syarat apa pun asalkan hal tersebut merupakan kesepakatan kedua belah pihak. Pendapat ini berbeda dengan pendapat ulama Syafiiyah, Zhahiriyah dan Syiah. Menurut mereka, setiap syarat yang dikumpulkan bersama akad jual beli hukum syaratnya batal.

Dalam kasus ini yang rajih menurut pendapat ulama, terutama ulama kontemporer, adalah pendapat pertama dari ulama Hanafiyah dan Malikiyah, dilihat dari berbagai aspek terutama aspek maslahat dan keridlaan kedua belah pihak atas syarat tersebut.

Dari dua contoh di atas terlihat bahwa istibsan yang digunakan oleh para ulama Hanafyyah, Malikiyah dan sebagian Hanabilah menghasilkan produk hukum yang berbeda dengan ulama lainnya. Walaupun dari segi dalil mereka lebih banyak mengedepankan maslahat umum daripada nas

${ }^{37}$ Rachmat Syafie'i, MA, op.cit., hlm. 114 
yang ada. Keberadaan istibsan sebagai dalil syarâ dan metode ijtihad memudahkan masyarakat muslim untuk saling berinteraksi antarsesama.

\section{Kesimpulan}

Dari uraian dan pembahasan yang dipaparklan di atas dapat diambil beberapa kesimpulan sebagai berikut:

1. Perbedaan pendapat mengenai istihsan sebagai dalil syarâ bersumber dari perbedaan pandangan mengenai pengertian istibsan itu sendiri. Pada hakekatnya, semua ulama menggunakan maslahat sebagai maqashid syâriah (tujuan syariat) di dalam ijtihad mereka, sementara maslahat adalah masalah pokok dalam persoalan istibsan.

2. Meskipun para ulama berbeda pendapat mengenai kehujjahan istibsan, secara substantif mereka sama-sama menggunakannya di dalam istimbath hukum. Para ulama Hanafyah, Malikiyah dan sebagian Hanabilah adalah pendukung dan pengguna istibsan dalam ijtihad mereka; sementara Imam Syafii dan pengikutnya menolak penggunaan istibsan sebagai dalil syara', namun dalam beberapa hal mereka menggunakannya meskipun mereka tidak menyebutnya sebagai istibsan.

3. Meskipun secara substantif para ulama sama-sama menggunakan istibsan, perbedaan pandangan mereka tentang perngertian istibsan mengakibatkan terjadi perbedaan hukum yang dihasilkan dalam istimbath.

4. Penggunaan istibsan yang dilandasi oleh nas dan tidak didasarkan kepada keinginan hawa nafsu dapat memberikan jalan keluar terhadap berbagai problema hukum Islam yang muncul di dalam perkembangan dunia modern.

\section{DAFTAR PUSTAKA}

Araby, Ibnu, Ahkeam al-Qurân, Dar al-Fikr, Beirut, t.th. vol. II.

Asyqar, Umar Sulaiman Abdullah Al-, Dr., Naz̧hariyat Fi Ushul al-Fiqh, Dar an-Nafâis, Oman, Cetakan kedua, 2004.

Bardisi, Muhammad Zakaria Al-, Usbûl Fiqh, Dar ats-Tsaqâfah, Kairo, 1996.

Hakim, Abdul Halim, Al-Bayân fi Tlmi Ushûlal-Fiqh, Darussalam Press, Gontor, t.th. vol. III.

Khudhary, Syekh Muhammad Al-, Ushâl Fiqh, Dâr al-Hadîs, Kairo, 2003.
Nur, Zainal Abidin al-'Abd Muhammad, Prof. Dr., Ra'yu Ushuliyyîn fi Mashâlih al-Mursalah wa al-Istibsan, Darul Buhuts li al-Dirasah al-Islamiyah wa 'Ihyâ Turats, U.A.E, 2004, vol. II.

Qaradhawy, Yusuf, Dr., Fatâwâ Mu'ashirah, Dar al-Qalam, Kairo, 2003, vol. 1.

Qarafy, Imam Al-, Nafầis al-Ushôl fi Syarh alMabshul, Maktabah Nubbaz Musthafa alBaz, Makkah al-Mukarramah, t.th, vol. III.

Syafie'i,. Rachmat Prof. Dr. H., M.A, Ilmu Usbul Fiqih, Pustaka setia, Bandung, Cetakan Pertama, 1999.

Syafii, Muhammad bin Idris Asy-, Al-Umm, Dar alKutub al-Ilmiyah, Beirut, Cetaka Pertama, 2002, Jilid 7.

Yahya, Mukhtar, Prof. Dr., dan Prof. Drs. Fatchurrahman, Dasar-Dasar Pembinaan Hukum Fiqh Islami, PT Al-Mâarif, Bandung, 1986.

Yunus, Mahmud, Prof. Dr. H., Kamus Bahasa ArabIndonesia, PT Hidakarya Agung, Jakarta, Cetakan Kedelapan, 1990.

Yusuf, Muhammad bin (Abu Hayyan al-Andalusi), Al-Babral-Mubith, Dar al-Kutub al-Ilmiyyah, Beirut, 1993.

Umam, Chaerul, Drs., dkk., Ushul Fiqh 1, Pustaka Setia, Bandung, Cetakan Kedua, 2000.

Zahrah, Muhammad Abu, Ushûll Fiqh, Dâru'l fikri al-Araby, Kairo, 2004.

Zaidan, Abdul Karim, Dr., Al-Wajiz, fi Ushul alFiqh, Muassasah ar-Risalah, Beirut, Cetakan Kelima, 1996.

Zuhaili, Wahbah Az-, Prof. Dr., Ushâl al-Fiqhi alIslâmîy, Dâr al-Fikr, Damaskus, Cetakan Ketiga, 2005, juz 2 